\title{
BLOOD AMYLASE ACTIVITY IN DISEASE OF CARBOHYDRATE METABOLISM AND IN NON-DIABETIC PANCREATIC DISEASE ${ }^{1}$
}

\author{
By S. Z. SORKIN 2 \\ (From the Laboratories of the Tufts Medical School at the Boston Dispensary, and \\ the Joseph H. Pratt Diagnostic Hospital, Boston)
}

(Received for publication July 2, 1942)

Thus far, no role has been established for the enzyme amylase in the intermediate carbohydrate metabolism. The recent work of Cori and coworkers $(1,2)$, and of Ostern, Herbert, and Holmes (3), makes it appear highly improbable that amylase participates in the carbohydrate metabolism of liver, muscle, and other tissues. A previous communication (4) reported enzyme studies on the liver tissue in glycogen-storage disease (von Gierke's disease), which failed to demonstrate any definite abnormality in liver amylase activity in this disease of carbohydrate metabolism. Nevertheless, abnormal blood amylase activity has often been reported in the common diseases of carbohydrate metabolism-diabetes and liver disease. In fact, only a single report ( $N \phi$ rby (5)) recording no alteration in the enzyme activity in diabetes is encountered. However, among the numerous other reports, there is marked divergence of opinion concerning the nature of the abnormality in amylase activity. Almost as many papers are found favoring an increase in blood amylolytic activity in these conditions as there are reporting the opposite, and indeed, experimental work is often presented to corroborate the findings, whether they be high or low (6).

These circumstances prompted a reinvestigation of blood amylase activity, with a revised method, in patients suffering from diabetes, hepato-cellular and other kinds of liver disease, and in a patient with glycogen-storage disease. In order to obtain a basis for comparison, similar determinations were carried out in a series of normal subjects and also in several children suffering from various

\footnotetext{
1 Work aided by a grant from the Rockefeller Foundation, the Bingham Associates Fund, and the Charlton Fund.

2 Work completed during tenure of Emanuel Libman Fellowship.
}

childhood diseases which do not affect the carbohydrate metabolism.

In sharp contrast with the divergent reports on blood amylase activity in disturbances of carbohydrate metabolism is the marked agreement of results recorded in acute disease involving the excretory function of the pancreas. Schlesinger (7), in 1908, demonstrated that ligation of the pancreatic ducts in animals produced increased blood amylase activity. Since that time, augmented blood amylase activity has been shown, by numerous authors, to bear a definite clinical and experimental relationship to this type of pancreatic disease, as is pointed out in recent articles $(8,9)$. It was, therefore, considered advisable also to determine the blood amylase activity in this disease category with the revised method.

The basis for an entirely reliable method for the determination of blood amylase activity lies in the following facts: (1) The hydrolysis of starch to reducing sugars by amylase takes place as a monomolecular reaction during a certain phase of the splitting $(10,11)$; and (2) these sugars, chiefly maltose, can be measured with a high degree of accuracy. A method was devised which includes fractional splitting as an integral part of the procedure, thereby assuring measurement of the hydrolysis during its monomolecular phase. Hanes' (12) modification of the Hagedorn-Jensen method was employed to estimate the reducing sugars formed, since this method yields accurate results for such sugars in the presence of starch. The amylase method, therefore, is based on the saccharifying power of the enzyme. This basis of measuring amylolytic activity was first popularized by $\mathrm{Kjeldahl}^{3}$ in 1880 . Since that time the saccharification method has been employed in modified form by many authors including Sherman et al. (10), Willstätter et al. (11), Somogyi

\footnotetext{
${ }^{3}$ Quoted by Sherman et al. (10).
} 
(13), and others. The method described in this paper offers the advantage derived from the fractional splitting which is incorporated. This makes it possible to ascertain in each instance whether or not the determination was made during the monomolecular phase of amylolysis.

\section{METHOD}

There are three parts: I. The enzymatic hydrolysis of starch; II. deproteinization of serum proteins; III. determination of the reducing substances formed. Interruption may be made between any of the parts.

The reagents used are as follows: Substrate, 1.4 per cent water clear solution of soluble starch (KalbaumZulkowsky); $\mathrm{M} / 15 \mathrm{Na}_{2} \mathrm{HPO}_{4}$ and $\mathrm{KH}_{2} \mathrm{PO}$, buffer having a $\mathrm{pH}$ of 6.8 ; activator, $\mathrm{M} / 5 \mathrm{NaCl} ; 1 \mathrm{~N} \mathrm{HCl}$ and $\mathrm{NaOH}$; 10 per cent neutral sodium tungstate ${ }^{4}$; and the reagents for the Hanes' method.

Part I. Place $25 \mathrm{cc}$. of substrate, $15 \mathrm{cc}$. of buffer, $5 \mathrm{cc}$. of activator, and $2.5 \mathrm{cc}$. of distilled water in a $125 \mathrm{cc}$. Erlenmyer flask. The latter is immersed in a thermostatically controlled waterbath, kept at $37^{\circ} \mathrm{C}$. for the duration of the hydrolysis. When the temperature of the contents of the flask reaches $37^{\circ} \mathrm{C}$., $2.5 \mathrm{cc}$. of serum are added with continuous shaking, and immediately thereafter $10 \mathrm{cc}$. of the flask's contents are transferred to a $15 \mathrm{cc}$. centrifuge tube containing $1 \mathrm{cc}$. of $1 \mathrm{~N} \mathrm{HCl}$ (the $\mathrm{HCl}$ inactivates the enzyme and also facilitates the precipitation of the proteins in Part II). The time is noted. Three subsequent $10 \mathrm{cc}$. samples are similarly treated at exactly 20, 40, and 60 minutes later. Thus, 4 aliquot fractions are obtained, each containing $0.5 \mathrm{cc}$. of serum. The first fraction removed serves as the blank.

Part II. Deproteinization is accomplished by adding $2 \mathrm{cc}$. of the sodium tungstate to each fraction, stirring, and centrifuging for 5 minutes. The water clear supernatant fluid is decanted into $50 \mathrm{cc}$. Hagedorn-Jensen tubes, each of which contains $1 \mathrm{cc}$. of $1 \mathrm{~N} \mathrm{NaOH}$ to neutralize the $\mathrm{HCl}$ used in Part I.

Part III. The amount of reducing substance in each fraction is measured by the Hanes' method.

The method of calculating the amylolytic activity and several examples to illustrate the findings in normal human serum are given in Tables I and II. The average 20-minute sodium thiosulfate titration value is multiplied by 2 , to obtain the value for $1 \mathrm{cc}$. of serum, and by the conversion factor for maltose $(0.55)$. The product thus obtained is multiplied by 3 to obtain the amount split in 1 hour (i.e., the measure of the amylolytic activity of the serum).

It will be seen from Tables I and II that a straight line type of curve is obtained if the amount of reducing substance found in the fractions is plotted against the time elapsed.

4 Since the samples must be neutral before Part III is carried out, the $1 \mathrm{~N} \mathrm{HCl}$ and the $\mathrm{NaOH}$ must be made up accurately, and the sodium tungstate should give a neutral reaction with litmus.

TABLE I

Normal human serum

\begin{tabular}{c|c|c|c|c}
\hline \hline \multirow{2}{*}{ Subject } & \multicolumn{3}{|c}{$\mathrm{N} / 75 \mathrm{Na} \mathrm{S}_{2} \mathrm{O}_{2}$ titration values of the fractions } \\
\cline { 2 - 5 } & Blank & 20 minutes & 40 minutes & 60 minutes \\
\hline A & 7.07 & 6.07 & 5.08 & 4.05 \\
B & 6.80 & 5.00 & 3.30 & 1.44 \\
C & 6.96 & 5.86 & 4.78 & 3.60 \\
D & 7.90 & 7.08 & 6.28 & 5.46 \\
E & 7.19 & 6.80 & 6.44 & 6.05 \\
\hline
\end{tabular}

TABLE II

Calculation of amylolytic activity

*Titration value of blank

Titration value of fractions

Increment in 20, 40, 60 minutes

Increment in each 20 minutes

Average 20-minute titration value $=1.00 \mathrm{cc}$.

$1.00 \times 2 \times 0.890 \dagger \times 0.55 \times 3$

$=2.94$ mgm. maltose $1 \mathrm{cc}$. serum 1 hour

- The titration values are those of Subject A in Table I. $\dagger$ Correction factor for N/75 sodium thiosulfate used.

Modification of method for rapid determination. An accurate rapid determination in serum of high amylase activity may be carried out by making the following minor changes in the method. Add $0.5 \mathrm{cc}$. of serum and $4.5 \mathrm{cc}$. of water, instead of the quantities indicated above, and limit the hydrolysis to two 10 -minute periods. With this modified method, the amylase value in serum of high activity can be ascertained in less than one hour.

\section{NORMAL SUBJECTS}

The individuals examined included patients who had no evidence of organic disease, physicians and other hospital workers. It will be seen that the values, as shown in Table III, range between 0.5

TABLE III

Serum amylolytic activity in normal subjects

Mgm. maltose
split in 1 hour
0.5 to 1
1 to 2
2 to 3
3 to 4
4 to 5
5 to 5.5

Total subjects

Average splitting

Number of
subjects
1
5
11
4
3
1
25
$2.6 \mathrm{mgm}$.

and $5.5 \mathrm{mgm}$. (average $2.6 \mathrm{mgm}$.) of maltose split by $1 \mathrm{cc}$. of serum in 1 hour. For this reason, a unit of amylolytic activity for clinical purposes was established as equal to $1 \mathrm{mgm}$. of maltose formed by $1 \mathrm{cc}$. of serum in 1 hour under the conditions utilized in the method. 


\section{DIABETIC PATIENTS}

The blood of 56 diabetic patients was tested for its amylase activity. The majority of the patients were ambulatory. All grades of diabetes, with the exception of diabetic coma, and various age groups, were included. The results disclose the same range of amylolytic activity as was found in the normal individuals. No relationship to insulin therapy could be established.

TABLE IV

Serum amylolytic activity in diabetic patients

Amylase units
0.5 to 1
1 to 2
2 to 3
3 to 4
4 to 5
5 to 6

Total number of patients

Average activity in units
Number of patients

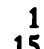

15

18

11

9

56

2.7

\section{PATIENTS WITH LIVER DISEASE}

This series includes 5 cases of toxic hepatitis, 1 of acute yellow atrophy, 5 of Laennec's cirrhosis ( 1 with intercurrent jaundice), 3 of cholelithiasis presenting no symptoms of pancreatic involvement, and 4 cases of obstructive icterus. The latter were of varied etiology: common duct stone, xanthomatous biliary cirrhosis, and carcinoma of the head of the pancreas. One case of congenital hemolytic icterus and one of hepatomegaly in a child with essential lipemia are also included in this group. From the findings shown in Table

TABLE $\mathbf{V}$

\section{Serum amylolytic activity in liver disease}

Disease

Acute yellow atrophy

Toxic hepatitis

Toxic hepatitis

Toxic hepatitis

Toxic hepatitis

Toxic hepatitis

Cirrhosis

Cirrhosis

Cirrhosis

Cirrhosis

Cirrhosis with intercurrent hepatitis

Cholelithiasis

Cholelithiasis

Cholelithiasis

Hepatomegaly (Essential lipemia)

Hemolytic icterus (Congenital)

Obstructive icterus (Choledocholithiasis)

Obstructive icterus (Choledocholithiasis)

Obstructive icterus (Xanthomatous biliary cirrhosis)

Obstructive icterus (Carcinoma of head of pancreas)
$\mathrm{V}$, it is seen that values similar to those in normal individuals were obtained in all instances except the one in which there was pancreatic involvement due to carcinoma of the head of the pancreas.

\section{PATIENT WITH GLYCOGEN STORAGE DISEASE}

A value of 2.2 units was found in the blood of a 3-day-old infant suffering from this disorder of carbohydrate metabolism. ${ }^{5}$ Autopsy subsequently revealed typical findings of markedly increased glycogen storage in the liver.

\section{PATIENTS WITH VARIOUS CHILDHOOD DISEASES}

The results of blood amylase determinations in 7 children suffering from a variety of diseases are given in Table VI. The values fell within the range found in the normal subjects.

TABLE VI

Serum amylolytic activity in disease in childhood

$\begin{array}{ll}\text { Chorea } & 5.50 \\ \text { Pneumonia } & 2.90 \\ \text { Rheumatic fever } & 2.25 \\ \text { Rheumatic carditis } & 3.10 \\ \text { Meckel's diverticulum } & 2.30 \\ \text { Essential xanthomatosis } & 2.40 \\ \text { Nephritis } & 4.35\end{array}$

PATIENTS WITH NON-DIABETIC PANCREATIC DISEASE

Frequent determinations were made in 4 cases of disease involving the excretory function of the pancreas (Table VII). One of the cases is that

TABLE VII

Serum amylase in non-diabetic pancreatic disease

\begin{tabular}{|c|c|c|c|c|c|c|c|}
\hline \multicolumn{2}{|c|}{ Pationt A } & \multicolumn{2}{|c|}{ Patient B } & \multicolumn{2}{|c|}{ Patient C } & \multicolumn{2}{|c|}{ Patient D } \\
\hline \multicolumn{2}{|c|}{$\begin{array}{l}\text { Carcinoms of head } \\
\text { of pancreas }\end{array}$} & \multicolumn{2}{|c|}{$\begin{array}{c}\text { Acute pancreatic } \\
\text { ederns }\end{array}$} & \multicolumn{2}{|c|}{$\begin{array}{l}\text { Aoute pancreatic } \\
\text { edems }\end{array}$} & \multicolumn{2}{|c|}{$\begin{array}{c}\text { Acute pancreatic } \\
\text { edems }\end{array}$} \\
\hline Date & $\begin{array}{l}\text { Amylase } \\
\text { units }\end{array}$ & Date & $\underset{\text { units }}{\text { Amplase }}$ & Date & $\underset{\text { units }}{\text { Amylase }}$ & Date & Amyiase \\
\hline $\begin{array}{l}\text { April 27 } \\
\text { May } 2 \\
\text { May } 4 \\
\text { May } 7 \\
\text { May } 25 \\
\text { May } 30\end{array}$ & $\begin{array}{l}39.96 \\
43.71 \\
43.02 \\
36.15 \\
40.60 \\
50.40\end{array}$ & $\begin{array}{ll}\text { May } & 4 \\
\text { May } & 5 \\
\text { May } 7 \\
\text { May } 12\end{array}$ & $\begin{array}{r}24.04 \\
12.70 \\
3.25 \\
3.00\end{array}$ & $\begin{array}{l}\text { May } 17 \\
\text { May } 18 \\
\text { May } 19 \\
\text { May } 21 \\
\text { May } 22 \\
\text { May } 23 \\
\text { May } 24\end{array}$ & $\begin{array}{r}\mathbf{5 5 . 2 9} \\
\mathbf{9 . 0 7} \\
\mathbf{8 . 1 0} \\
\mathbf{7 . 2 0} \\
\mathbf{5 . 4 0} \\
\mathbf{5 . 9 0} \\
\mathbf{5 . 4 0}\end{array}$ & $\begin{array}{l}\text { May } 25 \\
\text { May } 27 \\
\text { May } 28 \\
\text { May } 30\end{array}$ & $\begin{array}{r}49.20 \\
17.14 \\
8.23 \\
1.60\end{array}$ \\
\hline
\end{tabular}

of the patient with carcinoma of the head of the pancreas included in Table VI. The other 3 were those of patients who entered the hospital with a

5 The blood from this patient was obtained through the kindness of Dr. Elmer Barron and Dr. Francis MacDonald of the Boston Floating Hospital. 
clinical picture characteristic of acute pancreatitis. $^{6}$ The subsequent course and the clinical investigations carried out made it possible to establish the diagnosis of acute pancreatic edema, secondary to cholelithiasis, in each of the cases.

A maintained increase of the blood amylase was present in the patient with the carcinoma of the head of the pancreas. The patients suffering from acute pancreatic edema exhibited initial elevations of considerable magnitude with a subsequent return of the amylase activity to a normal level within several days.

\section{DISCUSSION}

Non-diabetic pancreatic disease. The increased blood amylase activity as observed in all of the 4 cases in this group is in accord with the long established relationship between high blood amylase values and disease of this type. The short duration of the increased activity in acute pancreatitides has also been well established clinically (14, 15) and experimentally (16), and the clinical value of the blood amylase determination in these conditions has been stressed (17). A maintained increase of amylase activity as observed in the patient with carcinoma of the head of the pancreas has not been reported previously. However, a persistent increase in serum amylase activity has been observed in dogs following permanent experimental closure of the pancreatic ducts (18).

Diseases of carbohydrate metabolism. The patients with diabetes, hepato-cellular liver disorders, and the one patient with glycogen storage disease, all exhibited normal blood amylase values. These findings are in keeping with the fact that no role has been found in the intermediary carbohydrate metabolism for this enzyme, despite the recent advancement of knowledge in this field. Recent contributions $(2,3)$ demonstrate the presence in liver, muscle, and other tissues, of a reversible glycogen-glucose conversion mechanism which depends on a specific phosphorylase-phosphatase enzyme system. This work also supplies experimental evidence that the mechanism is capable by itself of fulfilling the body's requirements for glucose obtained from glycogen stored in the liver,

6 The study of these patients was made possible through the cooperation of Dr. Stephen Maddock, Director of the Surgical Research Laboratories of the Boston City Hospital. and makes it appear highly improbable that amylase participates in this essential phase of intermediary carbohydrate metabolism (1).

Liver tissue possesses amylolytic activity, but this activity probably results mainly from the amylase contained in the hepatic blood and not in the liver cells proper $(19,1,8)$. However, regardless of its source, there is no proof that the amylase present in the liver has a function in carbohydrate metabolism. Conversely, there are reasons which make it doubtful that it has any function in the liver. The activity of the enzyme which is but slight in human blood is even less marked in liver tissue. In duodenal juice, where it plays a known role in the digestion of carbohydrates, the amylase is more than one thousand times $^{7}$ as active as that of blood or liver. Furthermore, amylase hydrolyzes starches to dextrins and to maltose as an end product (20), and, in physiological concentration, not at all or only in small amounts to glucose (21). The presence of the chief split products of amylolysis, maltose and non-fermentable reducing substances, cannot be demonstrated in liver tissue (8). Were maltose to be formed as an intermediary product and rapidly converted to the tissue utilizable glucose, the aid of a highly active maltase would be required. The latter enzyme is not known to be present in the human liver.

At present, therefore, there is no proof of the participation of amylase in the intermediary carbohydrate metabolism. The recent work and the other evidence mentioned militate against such an assumption. In accord with this are the normal blood amylase findings in diseases of carbohydrate metabolism, as reported in this paper. These findings may, therefore, be considered as clinical evidence pointing in the same direction.

\section{SUMMARY AND CONCLUSIONS}

1. The blood amylolytic activity of 25 normal patients was found to be between 0.5 and 5.5 mgm. (average $2.6 \mathrm{mgm}$.) of maltose per cc. of serum per hour, with the method described.

2. A clinical unit of amylolytic activity was established as equal to $1 \mathrm{mgm}$. of maltose formed in 1 hour by $1 \mathrm{cc}$. of serum.

\footnotetext{
7 Unpublished data.
} 
3. Normal blood amylase values were obtained in 56 diabetics, 11 patients with hepato-cellular liver disease, 8 with other types of liver disturbance, and 1 with glycogen storage disease.

4. Markedly increased blood amylase activity of transitory duration was observed in 3 patients with acute pancreatic edema; similarly augmented activity, but of a persistent nature, was found in a patient suffering from a carcinoma of the head of the pancreas.

5. The increased blood amylase activity encountered in the 4 patients with disease involving the excretory function of the pancreas is in accord with the clinical and experimental findings of numerous other authors.

6. The normal blood amylase values in disease of carbohydrate metabolism is offered as clinical evidence of the non-participation of amylase in the intermediary carbohydrate metabolism.

The author gratefully acknowledges the guidance given him by Dr. S. J. Thannhauser in carrying out this study.

\section{BIBLIOGRAPHY}

1. Cori, G. T., Cori, C. F., and Schmidt, G., The role of glucose-1-phosphate in the formation of blood sugar and synthesis of glycogen in the liver. J. Biol. Chem., 1939, 129, 629.

2. Cori, C. F., and Cori, G. T., Carbohydrate metabolism. Ann. Rev. Biochem., 1941, 10, 151.

3. Ostern, P., Herbert, D., and Holmes, E., Formation and breakdown of glycogen in the liver. Biochem. J., 1939, 33, 1858.

4. Thannhauser, S. J., Sorkin, S. Z., and Boncoddo, N. F.: The amylolytic and phosphatase activity of liver tissue in von Gierke's disease. J. Clin. Invest., 1940, $19,681$.

5. N $\phi$ rby, G., The amylase concentration in the serum of diabetics. Acta. med. Scandinav., 1936, Supp., 78, 933.

6. Oppenheimer, C., Die Fermente und ihre Wirkungen 5. Aufl. Supplement Bd. I. Spec. Teil, Junk Verlag, Haag, 1936, 469.
7. Schlesinger, W., Ueber den Ursprung des diastatischen Fermentes im Blute und über seine Beziehungen zum Diabetes mellitus. Deutsche med. Wchnschr., $1908,34,593$.

8. Somogyi, M., Diastatic activity of human blood. Arch. Int. Med., 1941, 67, 665.

9. Heifetz, C. J., Probstein, J. G., and Gray, S. H., Clinical studies on blood diastase. II. Significance of increased blood diastase. Arch. Int. Med., 1941, 67, 819.

10. Sherman, H. C., Kendall, E. C., and Clark, E. D., Studies on amylases. I. An examination of methods for the determination of diastatic power. J. Am. Chem. Soc., 1910, 32, 1073.

11. Willstätter, R., Waldschmidt-Leitz, E., and Hesse, A. R. F., Ueber Pankreas-Amylase. Ztschr. f. physiol. Chem., 1923, 126, 143.

12. Hanes, C. S., An application of the method of Hagedorn and Jensen to the determination of larger quantities of reducing sugars. Biochem. J., 1929, 23, 99.

13. Somogyi, M., Micromethods for the estimation of diastase. J. Biol. Chem., 1938, 125, 399.

14. Skoog, T., Uber funktionelle Pankreasdiagnostik im Harn, mit besonderer Berück sichtigung der Wohlgemuthschen Diastasereaktion. Acta chir. Scandinav., 1928, 63, 374.

15. Elman, R., The variations of blood amylase during acute transient disease of the pancreas. Ann. Surg., 1937, 105, 379.

16. McCaughan, J. M., Diagnosis of pancreatic disease. Proc. Soc. Exper. Biol. and Med., 1939, 40, 665.

17. Pratt, J. H., Diseases of the pancreas. Oxford Medicine, 1939, III, 473.

18. Golden, L. A., Sieracki, L. A., Handelsman, M. B., and Pratt, J. H., Diastase activity of blood and urine when the pancreatic ducts are permanently closed. Am. J. Digest. Dis., 1939, 6, 327.

19. Davenport, H. A., On liver amylase and its probable role in the regulation of blood sugar. J. Biol. Chem., 1926, 70, 625.

20. Pringsheim, H., The Chemistry of the Monosaccharides and of the Polysaccharides. McGraw-Hill, New York, 1932, p. 247.

21. Somogyi, M., Interpretation of the saccharogenic action of diastase on the basis of substrate competition. J. Biol. Chem., 1940, 134, 301. 